\title{
Critical Analysis of Some Well-Intended Proposals to Fight Unemployment
}

\begin{abstract}
In this paper it is asked whether it is meaningful to state a 'right to work' as a basic human right to be written down in the constitution, for example, whether working time should generally be reduced, and whether those who do not have (or find) a job should get a guaranteed minimal income. All three demands have to be rejected, at least in the radical form in which they are often stated. They cannot be realised at all or at least not without impairing other basic human rights. Finally, it is asked what can be retained from these (usually well-intended) demands.
\end{abstract}

\section{Introduction}

The functioning of the labour market or its regulation, respectively, is quite often the object of claims with an ethical demand, be it the demand for a right to work, a more equal distribution of the existing labour or a minimum wage (see, for example, papers in this volume, but also Gorz 1989; v. Parijs 1991; $1992 ; 1995$; Ulrich 1995; 1996). This is not astonishing as the labour market has some rather peculiar properties. On the one hand, it is functioning like any other market; there is supply and demand, and a contract is agreed upon whenever the wage offered for a job is higher than the reservation wage (i.e. the minimum wage that would be accepted) of the person who demands this job. On the other hand, labour markets are of utmost importance for most people in our society. We still live in a labour and consumption society where paid employment is crucial and the possibilities for consumption depend substantially on our labour income. These possibilities determine to a large extend the participation chances in our society. Thus, self-esteem as well as personal welfare largely depend on whether we have paid employment and on what kind of work we do. Only a very small part of the population is wealthy enough to finance a decent human life without any additional labour income. This means that most of those who do not have such an income sooner or later become dependent on others or on the government by receiving social assistance. The latter in particular not only largely reduces their consumption possibilities, but also impairs their self-esteem. As more recent studies for several countries show, unemployed persons are-ceteris paribus, i.e. with the same income-less satisfied with their life than employed 
people (see, for example, Gerlach/Stephan 1996; Di Tella/MacCulloch/Oswald 2001; Stutzer/Lalive 2002).

Because the labour market is so crucial for the life of the members of our modern society, there are strong incentives to regulate this market. On the one hand, this is done by establishing unions of employers and employees, i.e. bilateral cartels, in order to improve the bargaining situation in this market. On the other hand, the market is controlled by governmental regulations, for example with regard to occupational safety measures, minimum wages, or layoff rules. Such regulations do not necessarily, but might have the effect that the equilibrium in this market is lost because supply is larger than demand (oversupply) or demand larger than supply (overdemand). Overdemand does not pose any problems because rising wages will reinstall equilibrium, while oversupply causes problems because it leads to 'involuntary unemployment', i.e. a situation in which there are potential employees who are willing to accept a job in line with the existing wages and working conditions and who are also qualified for this work but who do not find a job because employment is 'rationed'.

In fact, Europe has been in such a situation since a long time. There is mass unemployment in many countries, sometimes with unemployment rates above 20 percent, in some regions even above 50 percent (on the analysis of the European development see, for example, Nickel 1997; Karanassou/Sala/Snower 2003; Blanchard 2006). This development started in the seventies of the last century, and while there was some indication of a significant reduction of the unemployment rate in recent years, the new financial and economic crisis threatens to lead (at least in some countries) to even higher levels of unemployment than before. At the moment, politics does not seem to be able to turn around this development.

Depending on the political view, there are different perspectives of this development. People on the right (bourgeois) side of the political spectrum, who have (at least to a large extent) accepted the neo-liberal paradigm of economic policy, complain that mainly labour market regulations lead to the obvious malfunctioning of this market. They therefore demand de-regulations, i.e. a reduction (or even abolishment) of minimum wages, a softening of layoff rules, or a reduction of unemployment benefits. ${ }^{1}$ Only a liberation of the labour market from its (governmental and other) ties can in the long run reinstall full employment. Positive examples of this approach can be seen in the United States, the United Kingdom, New Zealand, but also in the Scandinavian countries and the Netherlands, where employment has increased since the beginning of the nine-

\footnotetext{
${ }^{1}$ In Germany, this position is taken in particular by the 'Stiftung Marktwirtschaft'. See, for example, Deutschland im Reformstau, Argumente zu Marktwirtschaft und Politik 73, Oktober 2002, 3ff. (http://www.stiftung-marktwirtschaft.de/module/argument73.pdf, 05/04/09). But see also Siebert 1997 or Bertold 2001, as well as the critique of this orthodox view by Howell/Glyn/Baker/Schmitt 2007.
} 
ties. ${ }^{2}$ Last but not least, the Hartz legislation has contributed to a reduction of German unemployment during recent years. ${ }^{3}$

People on the left side of the political spectrum take quite a different stance. In their perspective, Germany has followed such a policy not only since the Hartz reforms but already since the 'change' in 1982 or at least since the beginning of the nineties, though without much success. In the Kohl area, besides other measures, property taxes were abolished and continued pay in the case of sickness as well as unemployment benefits were reduced, but there was no or at least no visible effect on unemployment. The same holds for the tax reductions during the first part of the Schröder government. The positive examples of the United States and the United Kingdom (and perhaps also of the German Hartz reforms) are acknowledged, but this goes at the expense of a growing number of 'working poor', i.e. of employees who do have a job but who do not earn enough for a decent human life (see, for example, Ulrich 1996, 21). From this perspective, a fundamental re-orientation of labour market policy is necessary (see, for example, Gorz 1989; Ulrich 1998).

We are therefore in a situation where, depending on the political (ideological) point of view, completely different conclusions are drawn from the failure of conventional labour market policies. It is possible to claim that these policies were wrong, the proof being their failure. But it is also possible to claim that they were unsuccessful because they were not forceful enough, and that today's situation could be much worse if the measures of the Kohl and Schröder governments had not been implemented. It is possible to argue for both positions consistently and plausibly.

The three perhaps most important policy options proposed by the critics of conventional labour market policy are the right to work, a general reduction of working time, and a guaranteed, unconditional minimal income, be it in the form of a basic income or a negative income tax. ${ }^{4}$ However, such proposals only make sense if they can be realised at all and without major negative side effects. Thus, before such demands are raised, their feasibility should be checked. ${ }^{5}$

This is to be done in this paper. We will ask whether it is meaningful to state a 'right to work' as a basic human right that is written down, for example, in the constitution (Section 1), whether working time should generally be reduced (Section 2), and whether those who do not have (or find) a job should receive a guaranteed minimal income (Section 3). The result of our analysis is that all three demands have to be rejected, at least in the radical form in which they are

\footnotetext{
2 See for this the corresponding contributions in Sarfati/Bonoli 2002.-For an overview of the unemployment development in the OECD countries since the last 20 years, see OECD 2008, 261ff.

${ }^{3}$ For a cautiously positive (but not undisputed) evaluation of the Hartz IV-reforms see Sachverständigenrat 2007, 341ff..

4 The claim for a guaranteed, unconditional basic income is the most popular one of these three claims at the moment. In 2006, there was even a new journal founded on this issue, Basic Income Studies.

${ }^{5}$ In particular in Germany, there is also a discussion about minimum wages, but here the objective is not a reduction of unemployment but the prevention of a class of working poor, even at the expense of some increase of unemployment. See for this debate, for example, Dolado/Felgueroso/Jimeno 2000; Boadway/Cuff 2001 and Knabe/Schöb 2008.
} 
often stated. They cannot be realised at all or at least not without impairing other basic human rights. Finally, it is asked what can be retained from these (usually well-intended) demands (Section 4).

\section{The 'Right to Work'}

Should we include the 'right to work', i.e. the right for a job with a sufficient wage to ensure a decent human life, as a basic human right into the national constitution, as this is done, for example, in article 23, clause 1, of the Universal Declaration of Human Rights of the United Nations: "Everyone has the right to work, to free choice of employment, to just and favorable conditions of work and to protection against unemployment." (For a discussion of this right see, for example, Mundlak 2007; Risse 2007.) This is exactly what is sometimes demanded. ${ }^{6}$ For such a demand to make sense, two conditions have to be fulfilled: First, it has to be justified why, in particular, a right for paid employment is demanded. Despite the fact that this demand currently has many adherents, it is by no means trivial to provide such a justification. No member of our society is forbidden to work, and there are many opportunities. The problem is to find an employment with an acceptable salary. Moreover, paid work is often not very pleasant; if we were not forced to work in order to finance our life, many of us would abstain from work (or at least from its unpleasant parts). But why should something be written into the constitution that many of us do not really strive for, because we only need it as a means for other purposes? Second, it has to be shown that the entitlements of the individuals resulting from such a constitutional right can be realised without (or at least without largely) impeding other basic rights of the individuals.

An attempt could be made to justify such a right with the argument that, as mentioned above, paid employment is the usual way to earn income in our society and that income is not only necessary to secure physical subsistence but that it also provides the means for a full participation in our society. ${ }^{7}$ It will hardly be questioned that people in our society need an income, but this argument does not imply that such an income necessarily has to come from paid employment. The argument shows at best that individuals have to have someculturally determined - minimal income, and that this income has to be above the physical subsistence income. This right might be connected to the obligation that, if possible, individuals have to do some work benefiting those who pay

\footnotetext{
6 See, for example, the Resolution über die Verankerung des Rechtes auf Arbeit im Grundgesetz der Bundesrepublik Deutschland in Moltmann 1979, 147f., but see also Pfannkuche 1996. Steinvorth 1996 also voted for such a right, but in the present volume (2009) he instead advocates a 'right to develop one's capabilities' which finally results in a demand for a basic income.-The right to work discussed here is totally different from the conception of the 'Right-to-Work Laws' in some U.S. states like Nevada, Utah, or Idaho. The purpose of these laws was that workers do not have to join a trade union or pay union member fees in order to get a job. See for this, for example, Moore 1998 or Dinlersoz/Hemández-Muurillo 2002.

7 Attempts to justify a right to work which came to the conclusion, though, that such a justification is not possible, have been performed, for example, by Elster 1988 or Rippe 1995.
} 
them; yet this does not include the right to a sufficiently paid employment in the (private) official economy.

Thus, a right to a sufficiently paid employment has to be justified differently. One might try to justify it by the self-esteem often connected with paid employment. However, this argument is not convincing either. Besides paid employment, there are many other ways to acquire self-esteem, for example by doing voluntary work in politics or social (non-profit) organisations or by bringing up children. This does not have always to be the case, but it can be, and self-esteem stemming from paid work would only be a strong argument for a right to work if this were the only or one of very few ways to acquire self-esteem. But this is not the case. There are many people who work to secure their livelihood and who do not gain any self-esteem from this work, but rather from other activities. Thus, the argument of self-esteem cannot provide a (convincing) justification for a right to work. Karl Marx, for example, considered wage labour, which is at stake here, as being 'estranged labour' and he hoped that it would be dispensable in the long-run. ${ }^{8}$ The claimed right to work is just a right to this estranged labour.

It might be argued that the (non-contested) fact that today paid employment is usually the basis of a personal income, allowing for full participation in society and finally also for self-esteem, is sufficient to justify a right to (paid) work. Relevant are those people who intend to do paid work for these motivations, but who are, for whatever reason, prevented from doing it, and not those who, also for whatever reason, do not intend to do such work. It is open to everybody not to use a right he or she is entitled to.

Then, at the latest, the question arises how this should be realised. In our society it is hardly possible to force single individuals (employers) to employ other people. This also holds for unions or associations: an employers' association can, for example, not force its members to create new jobs. And even if that were possible, a single employer cannot be forced to employ a particular unemployed person. This even applies if there are vacancies, should this specific unemployed person not have the necessary qualification. At best, it could be demanded that this person should get some money from this firm, and the firm should have the right to demand some work from him or her. As far as no suitable job is available, though, this is just another kind of hidden unemployment, where the unemployment compensation is paid by a private firm and not by the government. This would increase the wage bill of this firm and perhaps even endanger other jobs. Moreover, such an employment or unemployment, respectively, would hardly foster self-esteem. A legal claim against private employers on paid employment is therefore no option.

What remains is a legal claim against the government. It might have the obligation to provide all unemployed with paid employment. The government would thereby become their employer in public firms. This, however, creates several other problems as experiences with 'second labour markets' show. If the

8 See for this, for example, his elaborations about 'Estranged Labour' in Marx 1844, Part XXIIff..-On the other hand and considering only paid labour, v. Nell-Breuning states that every human work has "part in the nobility of the human person, in the human dignity" (1985, 139). 
public firm is in competition with a private one, i.e. if it produces the same goods as private firms, some of the latter will be crowded out and the jobs created in public firms will lead to the destruction of jobs at other places. The total effect on employment might even be negative, because the public firms will be less efficient due to the lower qualification of their employees. Therefore nothing is gained. This approach might even induce a spiral, and the government might end up being the only employer (in this sector of the economy). Not only the experiences of the 'real existing socialised economies' in Eastern Europe before 1990, where the right to work was - more or less - existing, show that this system hardly leads to a satisfactory societal solution. The reasons are the well-known informational problems which were largely discussed in the debate about the possibility of a competitive socialism between Lange and v. Mises and which demand a decentralised organisation of the economy, as often highlighted by v. Hayek (v. Mises 1920; Lange 1936; v. Hayek 1945).

Thus, public firms have to supply goods or services that are not produced by private firms. Today there is in fact a large area where labour could be productive but is not employed. This holds, for example, for large parts of the caring institutions. There is a demand for those services, but it does not appear on the market. The main reason for this is that hardly anybody is willing and/or able to pay market prices for these services. The government is already largely engaged in this sector, for example with public hospitals, but its involvement could still be extended. The main problem is how to finance it. Where private firms are unable to find a break-even, in most situations neither can the government. If the governmental involvement should be extended, additional money would be required. These jobs must substantially be financed through additional tax revenue, even if part of it would be re-financed by reduced unemployment payments.

This, however, causes other problems. The first one concerns the relatively simple question of how this measure is to be financed. A general tax increase would reduce the purchasing power of those who have to pay these taxes and might, therefore, endanger jobs at other places. The financing problem could be reduced considerably if the government would pay significantly lower wages than the private economy for equivalent jobs. This is done, for example, in Germany with respect to the civilian service, insofar as young men are employed in the social sector but do only get the military service payment for draftees, which is much below the wages usually paid in the caring sector. However, this example shows exactly the problems of such measures. First, it is a coercive measure that would hardly be possible in the private economy. Second, the amount of this payment (including the in-kind payment due to free accommodation and food) might be sufficient for a young man without family to finance his subsistence, but this wage is below the poverty limit and, under normal conditions, in no way sufficient. In Germany, these measures can be financed only under the abovementioned conditions, though. Third, these people are not in direct competition 
with workers seeking employment in the private sector. They therefore do not crowd out employment there. ${ }^{9}$

This shows the conditions that have to be fulfilled if such a second labour market is to increase employment. First, goods and services have to be supplied which are not produced in the private economy in order to prevent a crowdingout effect. Second, wages (for comparable employments) have to be significantly below those in the first labour market, not only to prevent incentives to switch from the first to the second labour market, but also to give those in the second market incentives to search for jobs in the first labour market. ${ }^{10}$ Both conditions imply that employment in the second market will hardly lead to the same self-esteem as employment in the first labour market. Employees in the second labour market will rather feel as second-class employees, and they will justifiably demand equal pay for equal work. This, however, leads to the problems mentioned above.

Thus one has to agree with Elster (1988) and Rippe (1995): "Every right to work which could be implemented is not desirable. It is impossible to realise a right to work connected with appreciation and self-esteem. Demanding such a right makes no sense." (Rippe 1995, 70f.) ${ }^{11}$ If a right to work should really be a right that could be sued, either the rule of equal pay for equal work would have to be violated by the government, which would considerably impair appreciation and self-esteem, or the government would in the long run (at least in some sectors of the economy) become the only employer and this would be the end of our liberal economic order. Such a right to work could at best be described as the obligation of the government to make every effort to achieve high employment in order to ensure that as many employees as possible find a suitable job. The above-mentioned article 24 of the Human Rights Declaration is no more than this, and such an obligation is also already laid down in article 1 of the German Stability and Growth Law of June 8, 1967, though it could not prevent the huge increase of unemployment since the seventies. This does not imply that this obligation should be abolished, but one should not expect too much from such formulas.

\footnotetext{
9 Nevertheless, some crowding out occurs: Public hospitals would need more regular employees if they could not fall back on those in the civilian service.

10 Steinvorth 1996, 94, arguing for a right to work, concedes this: "The rule could even be added that the wages for publicly initiated work are lower or the conditions stronger than in the private sector, if only some standards would be kept to."

11 See for this also Furger who classifies the right to work as a social human right but simultaneously concedes that this right "does not imply a direct legal claim for the single individual. The community could ensure this only under the condition of eventually forcing people to do some jobs and a limitation of individual freedom and personal human rights that is hardly tolerable." (1992, 163f.) - Both, Koller (2009, 13) as well as Steinvorth (2009, 99) also agree that a right to work can, at best, be a moral claim to get an employment allowing a decent life in our society but is not a right to be secured by some governmental institution.
} 


\section{Reduction of Working Time}

If it is not possible to guarantee everybody an adequate job by writing a right to work into the constitution, then, the argument goes, all available jobs should at least be distributed more equally and therefore more justly. This might be done by a reduction of the working time. ${ }^{12}$ The usual way of doing this has been to demand a reduction of the weekly working time, especially the 35-hour week, but with a perspective of a further reduction to 20 to 25 hours (see, for example, Ulrich 1995,51$)$. The starting point is the popular rule of three. The quantity of available employment is assumed to be constant. The number of employed people is the quantity of available employment (measured in annual working hours) divided by the annual working time per employee. If the working time is reduced, employment is increased correspondingly. Originally, this reduction was demanded, by the German trade unions, for example, without cuts in pay, i.e. with full wage compensation. This would increase labour unit costs, which could endanger employment at home and lead to a transfer of jobs to other countries. As this would contradict the intention of the working time reduction, meanwhile this demand was dropped. Consequently, today the claim for a working time reduction is usually combined with a request to the employed employees to accept the necessary wage reduction in favour of the unemployed. (Nell-Breuning 1985, $72 \mathrm{ff} .$, also argues against full wage compensation using ethical arguments.)

It is not to be disputed that future development might lead to a further reduction of the weekly working time. This will not necessarily be the case, but it is possible. There is no compelling reason why the trend of recent decades should break off. The reason for this trend is probably that the demand for leisure time is increasing with rising income. It is to be questioned, however, whether such a reduction should be administered from above. Not only legal restrictions are problematic, but also those in collective wage contracts, as far as they contradict the needs and wishes of the employees. This is important in particular when it is totally open whether such a reduction will help to reduce unemployment.

Thus, in a first step the conditions have to be defined under which a reduction of the working time without wage compensation will increase employment. The rule of three mentioned above at least implicitly assumes that the redistribution of employment will not increase average costs. This means that (at least) two conditions have to be fulfilled: First, no additional capital (equipment) is necessary. This holds, for example, if a factory producing 24 hours per day is switching from three to four shifts. The situation is quite different, though, when there is only one shift in a plant and the common working time is reduced, which is the rule today. ${ }^{13}$ The necessary creation of new (physical) working places increases the capital-output ratio. If the production costs are to be kept constant, the working time reduction has to be connected with a reduction of the wa-

\footnotetext{
12 See, for example, Gorz 1989, 269ff., 319ff., but also Koller 2009, 14, who demands "the limitation of working hours" as well as "the restriction of multiple incomes" as elements of a policy "to achieving the greatest possible extent of employment".

13 This holds, of course, also for services.
} 
ge per hour (instead of a partial or even full wage compensation). Thus it is possible that costs increase and labour demand decreases, even without wage compensation. If social security contributions are, as usually, related to wages, cost pressure further increases because the basis for these contributions shrinks. If insurance benefits are not to be reduced, contributions have to be increased. This further reduces the net income of employees. It is therefore theoretically open whether a reduction of the weekly working time would lead to an increase or a reduction of employment. ${ }^{14}$ If, however, a reduction of the workweek leads to an increase in labour productivity, this could at least partly be compensated. But this fact would also reduce the incentive for the creation of new employment opportunities because the production loss would partly be compensated by increased productivity. In any case, it is to be expected that even without compensation, at best a part of the lost working hours would be compensated by new employment.

The second condition is that the transmission of information, i.e. when the work is handed over to the next employee, does not cause any problems. This should usually be the case with respect to assembly-line work. Therefore, the introduction of the 28-hour workweek by Volkswagen in 1994 is a good example to show where such a working time reduction can be handled without problems (see for this also Bogai 1994). Generally speaking, this should be possible whenever the information set is limited and the transmission can easily be standardised. Another example for this is the transmission of information about hospital inpatients. Problems arise, on the other hand, whenever this kind of standardisation is impossible or only possible at the expense of a considerable information loss. In such situations, information transmission becomes expensive. This problem might - at least partly - be lessened if the work is differently portioned, if, for example, it is distributed among 8 instead of 7 employees. However, this approach demands additional working places, thereby increasing costs again, and furthermore it is not always possible. Scientists might, for example, work in a team, but it is not possible for two scientists to halve their reading time and still be expected to possess the same knowledge for their research as before because their knowledge would then be fragmented.

This indicates that a shortening of the workweek might only lead to a very limited creation of new employment (if at all) and, consequently, only to a small reduction of unemployment. ${ }^{15}$ One might argue against this that a wage reduction should be accepted if this should appear to be really necessary. ${ }^{16}$ After all, the objective is that all those who intend to be employed are employed, and a reduction of the nominal wage may partly be compensated by lower social se-

\footnotetext{
14 For theoretical papers about a reduction of the working time see, for example, the seminal paper by Calmfors/Hoel 1988, but also Marimon/Zilibotti 2000 or Huang/Chang/Lai/Lin 2002. An overview of this literature is given in Kapteyn/Kalwij/Zaidi 2004, 295ff..

15 Additionally, it has to be taken into account that the unemployed usually do not have the qualifications necessary for newly installed working places. This would again reduce the employment effect of the working time reduction. On the relevance of this 'mismatch-unemployment' for Germany see, for example, Entorf 1996.

16 However, this demand is problematic for low income earners whose salaries are often not much above the subsistence level.
} 
curity contributions, which increases real net wages. Moreover, these arguments are directed against a shortening of the workweek and do not necessarily apply to other kinds of working time reduction as well. The same arguments might (at least in small and medium enterprises) also hold for a prolongation of the vacation, but the situation is different if sabbaticals are introduced or granted more often. In this case, no additional working places have to be created. However, this might only be feasible without problems for large firms. Medium sized or small enterprises, which might only have one employee for a specific area, would be faced with the problem to train a temporary employee, entailing non-negligible costs again. Moreover, such firms might come into financial problems if one out of very few employees requires a sabbatical and the firm is required to hire a temporary employee. Such cases could be subsidised, partly by the government, but then the public finance problems mentioned above arise again.

Taking all these arguments together, a legally prescribed reduction of the working time would at best lead to a small reduction of unemployment. Nevertheless, such a measure could still be supported because at least it goes into the 'right' direction. There are, however, several other problems, at the positive as well as at the normative level. Let us consider the claim of Ulrich $(1996,27)$ for the "institutionalisation of a general civil right for a normalised life working time" and let us assume that somebody was studious and hard working and therefore fulfilling his 'normalised life working time' by the age of fifty. This could be easily achieved if the regulated average weekly working time is 35 or even only 30 hours. Can we deny the right of this person to seek for further paid employment? And which police state measures should be employed to enforce this limit? And what about the wealth of our society if, in particular, highly productive (and motivated) people, who usually work longer than the average employee, are forced into (very) early retirement? Are we not faced with the problem that, given today's unemployment, this is already done much too often? And should the government be advised to enforce this even more?

If at all, a life working time, limited by legal regulations, can therefore only be enforced by a reduction of the weekly working time, additional vacation (including sabbaticals) or early retirement. All three solutions have severe problems. But how can compulsory measures against the preferences of many people affected by them be justified at all? What is the moral or ethical justification to prohibit citizens from working longer and having higher incomes, if this is what they really want? And what reactions do we have to expect?

One often-heard argument is that only a significant and legally enforced reduction of the weekly working time leads to an equable distribution of employment work among both sexes (see, for example, Baum 1995; Ulrich 1995). Thus, a public intervention into the inner-familiar division of labour is demanded, to make the private room public, as Baum (1995, 32) states. However, the Scandinavian experience, where the female labour participation rates are quite close to the male rates, shows that a more equal distribution can also be brought about by other measures and without such a strong public intervention into the private sphere. ${ }^{17}$ Moreover, the moral justification for strong interventions (with

17 The Swiss female labour participation rate is also very high. However, the average weekly 
their side effects) is still unclear. Even if there are good reasons for a more equal distribution of paid and homework within the families, this must not necessarily be the case in every single family. And what about those who do not have small children (or old parents needing care, respectively): Are they also prevented to work more than 25 hours per week? How can such a restriction of personal freedom, which contributes nothing to a more equal distribution of labour among the sexes, be justified? Do we want, for example, a publicly organised and legally enforced nursing service where every man and every woman has to work 10 hours every week? Such an authoritarian and enforcing state can hardly be the solution for today's unemployment problem.

However, there is another, and perhaps somewhat better argument for a general reduction of the working time. It can be seen as a public good benefiting all of us. Let us assume that, according to our preferences, a weekly working time of 38 hours would be optimal. Individually, it would even be better for us if all others kept to this limit except ourselves. If this holds for all of us, everybody has an incentive to behave as a free rider. The only way to achieve the socially optimal situation is a generally agreed and implemented upper limit. This argument might be used to justify such a limitation even if we observe that such limits are always transgressed wherever attempts are made to install them. Interpreting such a limit as a merit good could lead to a similar result. Then it must be distinguished between actual and superordinated (moral) preferences and it must be assumed that we intend to have such a limit according to our moral preferences but behave differently according to our actual, subordinated preferences. (Such distinctions are employed, for example, by Frankfurt 1971; Sen 1977.) A legal restriction could be interpreted as a collective self-restraint and, according to Maital (1986), it would be a "welfare-improving constraint". (See for this also Schelling 1978; 1980, as well as the contributions in Elster 1987. Such a justification for merit goods is provided by Brennan/Lomasky 1984.)

However, such an attempt to justify a general limit of the weekly working time also has to take into account possible negative side effects. Aside from school education we rarely use compulsory measures to provide merit goods. Usually, incentives to consume such goods are increased with subsidies, and only their financing is done using compulsory measured, i.e. general taxes.

All these arguments suppose that employment is indeed increased by a shortening of the working time. Empirical studies show, however, that this is highly questionable. This already holds for the first German studies undertaken in the eighties when the 35-hour week was a hot political topic. Stille and Zwiener (1983), for example, estimate that if the 35-hour week were introduced, only 40 percent of the theoretically possible employment increase would actually be realised. König and Pohlmeier (1987) as well as Kraft (1988) were even more sceptical with their empirical results. More recent empirical studies do not present a more optimistic picture either. They show three effects. First, after the introduction of the 35-hour week, wage compensation took place, which prevented a significant employment effect. Hunt (1999) shows this for Germany, Skans (2004) for Swe-

working time is much below the one of men. Thus, the distribution of paid labour is considerably more unequal than is suggested by figures of the participation rates. 
den, and Kapteyn, Kalwij and Zaidi (2004) for a sample of 16 OECD countries. Second, the actual reduction of the working time was less than the formal reduction in standard hours, because overtime work was increasing. (See, for example, Skans 2004 for Sweden.) Third, the resulting employment effects are ambiguous. For France, Crépon and Kramaz (2002) find a negative effect, while Estevão and Sá (2008) find no effect at all. Hunt (1999) finds a reduction of employment in Germany, while Kapteyn, Kalwij and Zaidi (2004) in their sample of 16 OECD countries identify positive direct but also negative indirect employment effects that nearly compensate the direct effects. Only Bosch and Lehndorff (2001) find significant employment effects for several countries. Taking all available evidence together, though, the hope for an increase in employment by a reduction of the workweek is hardly supported by this evidence so far. ${ }^{18}$

Moreover, if we force the individuals to officially work fewer hours per week than they want, several side effects might emerge. People will sidestep into the shadow economy if they can use their abilities there. It is not a coincidence that the size of the shadow economy is the higher the shorter the official working time is. ${ }^{19}$ This can only (and only partly) be suppressed by policy measures. Second, overtime work is increasing. If employers and employees commonly want longer working times, they will arrange this in order to evade governmental regulations. ${ }^{20}$ This is particularly the case if there are tax preferences for overtime work as had long been the case in West Germany. Third, the divide in working load, but also in income, between employees and self-employed (or those who have discretion about their working time, respectively) will increase. The latter can hardly be forced to work less, and they will hardly do so whenever it is not in accordance with their preferences. This might increase the incentive to become self-employed, but also the incentive to dislocate employees in non-genuine freelancing (disguised employment). All these negative side effects, which can hardly be prevented and, if at all, only with a considerable amount of police operations, will probably more than offset the possible positive employment effects of a working time reduction. The claim for such a reduction can therefore hardly be justified even from an ethical perspective.

\footnotetext{
18 See also Conrad/Koeschel/Löschel 2005 who, in their CGE simulation study, do not find a negative employment effect for an increase of the workweek in Germany.

19 The relation between the effective working time and the size of the shadow economy in a country was investigated by Weck 1983 (see, in particular, 86ff.).--More recent surveys about the size of the shadow economy are presented by Schneider and Enste 2000 as well as by Schneider 2007.

20 The simultaneous occurrence of high unemployment and a high number of overtime hours as could be observed, for example, in the Federal Republic of Germany, is, however, only partly due to short working time; a more important factor might be the restrictive layoff rules and the layoff costs resulting from these rules. Whenever the demand for their products increases, employers will in such a institutional environment hire additional workers only if they are pretty sure that the increased demand is enduring. As long as they have to take into account that this demand will probably be shrinking again, they will try to organise the additional production as far as possible by using overtime (or by hiring people from temporary employment firms) in order to avoid additional costs resulting from layoffs which might become necessary later on. See for this, for example, Siebert 1987.
} 


\section{Negative Income Taxes and Basic Income}

If it does not make sense to lay down a right to work in the constitution because the government cannot afford to implement this right (in a liberal society), and if a general reduction of the working time is no adequate means to fight mass unemployment, it is only natural to claim that all citizens should have a guaranteed income that covers at least their (culturally defined) subsistence. This claim is largely undisputed. In contrast, the amount of such an income as well as the question of who should be entitled to it are disputed. Today, those who qualify for a guaranteed income are obliged to prove their need. This means that they are petitioners vis-à-vis the public bureaucracy, giving the latter considerable discretionary power. This kind of assistance is not only in many cases economically inefficient (see for this, for example, Frey and Kirchgässner (2002, 279ff.), but it also contradicts consumer sovereignty or the autonomy of the person, respectively. What gives us the right to prescribe consumption possibilities for the poor, while we grant rich people full freedom to decide about their consumption? It is obvious that by doing so, the rights of people with low or even no own income are restricted.

Two proposals were made to solve these problems that are, however, more or less identical: the negative income tax going back to Rhys-Williams (1943), but popularised by Friedman (1962), and the idea of a guaranteed basic income. ${ }^{21}$ According to both concepts, citizens receive an unconditional income. In the case of a basic income, the amount is transferred to them in regular (for example monthly) tranches and taken into account in the tax declaration that has to be completed later on. In the case of the negative income tax, the citizen first has to hand in his tax declaration. If his income is above a certain limit, he has to pay taxes, if it is below this limit, he has to pay a 'negative tax', i.e. he receives a transfer. If he has no income at all, the transfer he gets is his guaranteed basic income. The financial means needed by the government to implement this system of a minimum income are in both cases the same, as always the same citizens are entitled to financial help.

At a first glance, this concept of a guaranteed minimum income is extremely attractive. It would not only stop the discrimination of the citizens in the lowest part of the income scale, but also restrict the discretionary power of the (social) bureaucracy. Moreover, those who can only receive a low wage would still have an incentive to work. In the current system of social assistance such income is in many cases totally offset against the assistance payments, i.e. the marginal tax rate is (sometimes even more than) 100 percent. Thus, recipients of social assistance often have no or at best rather weak incentives to accept a job in the official economy. The frequent (but quite often overestimated) complaint about the misuse of the social security system is virtually provoked by these incentives. Finally, the negative income tax allows for a wider spread of the wage scale and therefore supports the supply of jobs that are not competitive given today's

\footnotetext{
21 A (not entirely correct) comparison of the two concepts is given in Schneider 1995. An overview over the different variants is presented by Leu/Eisenring 1998. See for such a demand also Koller 2009, 19, as well as Steinvorth 2009, 105, in this volume.
} 
minimum wages. Such jobs could be supplied without the fear that a class of working poor comes into existence.

Given the many advantages of this system, it has to be asked why it has not been introduced a long time ago. Of course, the social bureaucracy, as any other bureaucracy, might oppose it with all reasonable (and perhaps also unreasonable) arguments, because this system would reduce its discretionary leeway. However, such a 'conspiracy assumption' is hardly sufficient to explain why such a system has never been introduced despite some experiments in the United States and Canada between 1968 and 1980. (The experiences of these experiments are discussed in Moffitt 2003; Widerquist 2005.) There are two major problems connected with this system, though. First, and this is the most important argument for the economist, this system can hardly be financed, and due of the enormous amount of money that would have to be raised by tax increases, it would not (or only to a small part) produce the intended positive employment effects. Second, this system is also highly debatable from an ethical perspective, because it would mean that hard-working citizens would subsidise lazy people. Thus, there are also ethicians who demand that such payments are only made under specific conditions (see, for example, Elster 1989, 215f.).

First of all and (not only) from an economic perspective, the impact of such a system depends on the answers to two questions: who is entitled to such an income and what is the amount of this income. A reasonable approach for the latter answer might be the poverty line; the basic income should at least not be below this line because it has to guarantee subsistence. A usual assumption for the poverty line is 40 percent of the average income. If-without any conditionality - every citizen were entitled to the basic income, in a first step the government would have to distribute 40 percent of GDP per capita among the population. A large amount of this money would be taxed away again but this would require very high marginal tax rates. If the average tax rate for the mean income were only 20 percent, this would imply marginal tax rates of about 60 percent. If one takes into account that, for retired people, this provides only a minimum income, an additional old age pension system would be needed which further increases the marginal burden. This would generate considerable negative incentives to work in the official economy, but provide positive incentives to work in the shadow economy, thereby increasing the marginal burden even further. Thus, without any conditionality, a guaranteed basic income or negative income tax cannot be financed and is, therefore, also not feasible. This applies all the more, the more generous the basic income is. (A very generous basic income is demanded, for example, by Schneider 1995 or Schaber 1996 but in particular by v. Parijs $1991 ; 1992 ; 1995$.) Thus, this system is not sustainable, even not in the sense of v. Parijs $(1995,30 f f$.$) .$

It is often stated that such a system would not be more expensive than the current social security system (see, for example, Ulrich 1995, 48). This, however, would only be true if the set of those who are entitled were severely restricted. This is impossible, though, if it is to be a really general basic income which would imply that not only those who are willing to work and those who are unable to work because they are handicapped and/or do not find a job receive 
such an income, but also those who reject to do paid work, be it that they have other engagements or that they just want to enjoy leisure. According to v. Parijs, "real freedom consists in the possibility to be able to select among those lives one wants to enjoy" (1995, 32f.). ${ }^{22}$ Thus, the working population, the unemployed and the pensioners would be entitled to this income, but also students or partners of high income earners without an own labour income. ${ }^{23}$ The result is not only that this system can hardly be financed, but that it also leads to those extremely high marginal tax rates that annihilate the positive primary working incentives or even revert them. ${ }^{24}$

If such a system is to be introduced - and there are a number of good reasons in favour of it - a limitation of the group of those who are entitled to a basic income is unavoidable. It would make sense to include pensioned people (due to old age as well as a handicap). For those who are unemployed but able to work, payment should be conditional on their willingness to work, as it is today with respect to unemployment insurance. Moreover, as done in some countries, it could be dependent on their work for the community, as long as appropriate jobs in a second labour market are available. The disadvantage is that a social bureaucracy would be needed again, even if it would be smaller than today, and that this bureaucracy would still have some discretionary power, in particular, if it must be decided whether somebody really makes an effort to find a job. Thus, the concept loses some of its charm.

But even then it is still not clear whether such a system can be financed. The main reason is that today take-up rates are relatively low; in Switzerland, take-up rates for social assistance are estimated to be only about 20 percent (Leu et al. 2007, 139). A general basic income would immediately require about five times more money than today, and this even if the group of those entitled would not change. Leu et al. (2007) prepared a study about the financial feasibility of an earned income tax credit system in Switzerland, presenting the first serious calculations for the introduction of such a system in Switzerland. These calculations show that abolishing the existing poverty traps alone would be rather costly and hardly possible without a reduction of the minimum income. Thus, the financial implications of this system are so severe that an unconditional basic income guaranteeing a decent life is impossible. There are, of course, quite a lot of proposals available, some even with calculations, that claim the feasibility of such a system. ${ }^{25}$ All these proposals suffer from two major drawbacks, though. The proposed basic income is considerably below the poverty line and/or the take-up rates are underestimated. Thus, either the guaranteed basic income is too low to live a decent life, or the system cannot be financed. ${ }^{26}$

\footnotetext{
${ }^{22}$ To make this decision possible, v. Parijs demands not only a generous amount but the highest possible amount of this income.

${ }^{23}$ Even if a large part of this income is taxed away again, an unconditional system would imply a subsidy for earners of high non-wage income. If the marginal tax rate is 60 percent, they could still keep 40 percent of the basic income.

${ }_{24}$ Here, we do not discuss the (also relevant) question whether this would cause migrations.

${ }^{25}$ See for example, the citizens' money ('Bürgergeld') as proposed by the German F.D.P. or the proposal of the CDU prime minister of Thüringen, Dieter Althaus.

${ }^{26}$ See for this also Harvey 2006. - The fact that "even conservative politicians and established
} 
Independent of whether such a system can be realised in a liberal society or not, the question can be asked whether it is morally right to make such payments unconditionally. It should be undisputed that those who are unable to take up employment as well as those who really make efforts to get employment but cannot find a job should be entitled. It is disputed, however, whether those who are able to work but do not want to should be entitled as well. The backside of the free decision between work and leisure for people who do not intend do work is that those who work in order to reach a higher than the minimum consumption level have to subsidise the others which makes working citizens feel exploited. Consequently, Frank (1985, 254ff.) as well as Elster (1988, 215f.) argue against an unconditional basic income, while for v. Parijs $(1991 ; 1992 ; 1995)$, for example, the unconditionality is the precondition for a real freedom to choose between leisure and work. (Similar arguments as by v. Parijs are used by Schaber 1996.)

The crucial question is whether there exists a moral duty of the working citizens to also provide those members of the society with the possibility of a decent life who are able to care for themselves but not willing to do so if they can avoid it. The above arguments which show that such a system would not be sustainable because the incentives to work would be so small that hardly anybody would have an interest to work (in the official economy) illustrate that such a duty cannot be justified. But one can at least perform the mental experiment and ask whether it could be justified if such a system were to function. But even then it is difficult to get a positive answer, despite the arguments presented by v. Parijs.

A suitable starting point is given by the contract theoretic approach, i.e. if the question is asked whether rational individuals behind a veil of ignorance would chose such a system of a guaranteed basic income. By following Harsanyi (1975; 1977) and applying the principle of maximising expected utility, it is obvious that such a proposal would have to be rejected. It might, however, be accepted when applying the difference principle according to Rawls (1971). Whether this is the case depends on the assumption about the least advantaged people. If they are those who can work but do not intend to work, following v. Parijs (1995), their income is to be maximised. A more reasonable assumption is, however, that the least advantaged people are those who would like to work but cannot do so, be it that they are unable due to physical reasons, or be it that they do not find a job. Following the difference principle their income is to be maximised. They are less privileged than the others because the voluntarily unemployed get only positive benefits from the leisure time connected with their unemployment while the involuntarily unemployed have to bear the psychic burdens mentioned above which for them are often even worse than the reduction of their monetary income. However, their income will be reduced if those who can work but do not want to do so also get a basic income. This implies that the least advantaged group is worse off if the basic income is unconditional compared to a situation where it is conditional. This violates the Rawlsian difference principle. Thus, in both

economists agree that a basic income that ensures a decent life and does not reduce production is possible" (Steinvorth 2009, 109) does not yet ensure that it is really feasible. Concrete calculations as, for example, for Switzerland in Leu et al. 2007, show the contrary. 
variants, this contract theoretic approach does not provide a moral justification for an unconditional basic income.

The same holds if we start from the concept of exchange justice as proposed, for example, by Höffe $(1990 ; 1994)$. In this approach, not only private but also public activities are primarily seen as (voluntary) exchanges. If we rely on the individuals' interests and demand that ethical norms should be acceptable to all affected individuals, voluntary exchange is a suited paradigm because all actions are performed with the consent of all affected individuals. Actually, many government activities, including parts of legally forced income redistribution, can be interpreted as voluntary exchanges. (On the different motives for income redistribution see, for example, Kirchgässner 1995.) Following this approach, the government (the working population who finances the social security system) can demand something in return for the transfers, at least as far as this is possible. For those who can work this would (at least) be the willingness to work. Only those who cannot work (or do not have to work for other reasons) are entitled to a basic income. This can be derived from the principle of 'corrective justice', which becomes relevant whenever the principle of exchange justice cannot be applied, because one of the partners is unable to provide his contribution..$^{27}$ Thus, the principle of corrective justice is subsidiary to the principle of exchange justice.

\section{Concluding Remarks}

The results of the three preceding sections can be summarised as follows: First, it does not make sense to claim a 'right to work' as an individual citizen's right to get appropriate employment with an adequate wage. In a liberal and democratic society there is no addressee who could guarantee that this entitlement can always be met. Second, a general reduction of the working time is no suited means to (significantly) improve the current situation of mass unemployment. Finally, a general, unconditional basic income is not feasible. Moreover, it also holds that none of these three claims can be convincingly justified. In all three cases there are arguments against these claims that are at least as convincing as those brought forward in favour of them. This even holds if we not only follow the contract theoretic approach by Rawls (1971), but also if we apply his difference principle that we allow inequality only as far as it is beneficial for the least advantaged in our society.

This sounds quite negative. It does, however, not change anything about the fact that today (mass) unemployment is a crucial economic and political problem and that politics as well as social sciences have the task, as far as ever possible, to find a remedy. Given today's situation on the labour market, the following

\footnotetext{
27 At a first glance, this is independent of the question of liability. According to this approach, even an individual who is unable to provide his contribution by his own fault is entitled to a subsistence income. He loses this right, of course, as soon as he is again able to provide his contribution. An open problem is, though, how far this creates incentives for moral hazard. It is not by chance that the same situation is usually evaluated quite differently in our society depending on whether the individual is responsible or not (and whether he acted intentionally or not).
} 
statements might be (largely) undisputed, i.e. subscribed by (nearly) all people, independent of their political and ethical position:

(i) If somebody becomes unemployed through no fault of his or her own, does not find a new job and has no other income, he or she shall be entitled to receive transfers that cover at least the expenses of the (culturally defined) subsistence level.

(ii) Because involuntary unemployment usually does not only lead to a monetary loss but also imposes considerable psychic burdens on those affected, it is the task of the government to provide conditions so that as many as possible searching a job also have the chance to find one.

(iii) The emergence of a class of 'working poor' is to be prevented. If labour income is not sufficient to guarantee a decent life and if no other income is available, the government is obliged to pay at least the difference between the wage and the subsistence income.

(iv) Transfers by the government should be provided as unbureaucratically as possible, i.e. power and leeway of the social bureaucracy have to be restricted as far as possible.

(v) This presupposes that the social security system is financed in a sustainable way that is and will not be undermined by developments connected with globalisation and international tax competition.

On the other hand, the size of the transfers, their (un)conditionality and perhaps also the way they are to be financed are disputed.

If unemployment is really to be reduced, new jobs have to be created primarily for those with low income and low (or even missing) qualification, because this is the segment of the labour market mostly affected by globalisation. This will hardly be possible without a larger spread in the wage scale. In order to still allow the workers most affected by this development to have a decent human life, additional payments by the government are necessary. Today, this is mostly done by the 'earned income tax credit', which has been applied, for example, in the United States and the United Kingdom. The results are only partly positive. ${ }^{28}$ Similar proposals have also been made for Germany. ${ }^{29}$

These additional payments might partly be financed by reduced unemployment benefits, but an increase of the government's share cannot be excluded. At the same time, capital can be less taxed than in the past because of its higher mobility. Thus, we are confronted with a situation where the (financial) demands on the public sector increase while at the same time the revenue from the current tax system tends to decline. ${ }^{30}$ If we want to escape this increasing divergence, we

\footnotetext{
28 Regarding the experiences in these and other countries see, for example, Leu et al. 2007, 113ff., especially for the United Kingdom also Blundell 2006.

29 See, for example, the contributions in ifo Schnelldienst 4/2007.

30 At the same time, the ageing population creates additional problems for the public finances.
} 
cannot avoid substantial changes of public finances at the expenditure and/or revenue side.

It has been shown that a system to finance our social security system can be found that is sustainable even under the conditions of today's globalisation (Kirchgässner 1998a). With respect to the tax system two directions have to be followed. First, the tax burden on enterprises has to be reduced. This holds in particular for those countries with still rather high corporate income taxes, and this is only possible by a higher burden on (natural) persons. Second, the tax burden on income should be reduced and the one on consumption increased. If the burden on labour income is reduced, this should be done rather by non-wage labour costs (social security contributions) than by a reduction of direct taxes. A (partial) shift from income to consumption taxes would also allow steps towards an ecological tax reform by reducing the tax burden on labour but increasing the burden on environmentally detrimental activities. This can be done, for example, by energy and/or $\mathrm{CO}_{2}$ taxes (see for this, for example, Kirchgässner 1998).

Thus, there are possibilities to comply with the objectives mentioned above. They are 'economical' in the sense that they start out from concrete interests of the individuals, and the proposed policy measures can be applied without violating basic human rights and liberties of the affected citizens. They are designed on the basis of the economic model of behaviour, the 'homo oeconomicus', ${ }^{31}$ i.e. it is assumed that the agents are autonomous individuals who react rationally, in accordance with their preferences, to these policy measures. This model of human behaviour, stemming originally from economics, is today applied in many other social sciences as well, and despite all known weaknesses which are increasingly investigated also by economists, it is still the most fruitful approach in the social sciences and without any alternative in economics as yet.

Today, we often speak of the end of the labour society. The demand for reductions of the working time also goes into this direction. This hypothesis is not new; 160 years ago, Karl Marx believed the labour society to come to an end soon (after the revolution). ${ }^{32}$ In reality, however, this might remain a nice dream for a long time to come (or possibly even forever). Thus, the measures proposed above do not exclude a shortening of the working time, but they also do not assume that paid employment will significantly be reduced even in the medium run. Despite high unemployment, we experience a quite different development today. Due to the increased female labour participation, paid employment has increased considerably in recent decades. A consequence of this development is that many services provided within the families in earlier times are now delivered via markets, i.e. with paid employment. This might be criticised as an 'economisation of the Lebenswelt' and a step backwards for society. Yet it must be accepted that this is a necessary consequence of women's emancipation; increasingly more women strive for their personal development in the professional sphere as well. This development will definitely not be reversed (see for this more extensively Kirchgässner 1997). Thus, for the near future we can rather expect

\footnotetext{
31 For a more detailed description of the economic model of behaviour see Kirchgässner 2008

32 See for this his answer on the $20^{t h}$ question "What will be the consequences [...]?" in the communist manifesto by Marx/Engels 1848 .
} 
a further extenuation than a reduction of paid employment. This fact has to be taken into account when designing labour market policy measures.

These considerations might be criticised as being too much 'economically' oriented. But a critical analysis of any economic policy measure, proposed by economists, ethicians, politicians or others, first of all demands a positive economic analysis although this is not everything that is needed. It cannot, in particular, substitute the political decision that has to be taken by the citizens and/or their representatives. These decisions should be informed, though, and to provide such information is the task of economic theorising. Thus, ethical discourses dealing with economically relevant questions will hardly be able to do without a solid economic analysis of proposed norms or measures if one does not want to deceive oneself (see for this also Gäfgen 1980). Due to the bridge principle 'ultra posse nemo obligatur', such an analysis is usually necessary if one does not want to miss the aspired objective (or to reach it at best by chance). The results of such an analysis might in many cases seem to be 'destructive', but they (hopefully) can save us from making some economic policy mistakes that often have high societal costs. A Nirvana approach comparing the current, unsatisfying situation with an ideal, but not realisable world does not help very much. What we need instead are practicable measures leading into the right direction, even if they represent only small steps.

\section{Bibliography}

Baum, A. (1995), Zum Verhältnis von Nichterwerbs- und Erwerbsarbeit, in: Gesellschaft zur Förderung der ethischen Forschung, Arbeitsblätter 34, 23-33

Boadway, R./K. Cuff (2001), A Minimum Wage Can Be Welfare-Improving and Employment-Enhancing, in: European Economic Review 45, 553-576

Bogai, D. (1994), Arbeitszeitverkürzung und Beschäftigung, in: Wirtschaftsdienst 74, $457-462$

Bertold, N. (2001), Das Bündnis für Arbeit: Ein Weg aus der institutionellen Verflechtungsfalle, in: Perspektiven der Wirtschaftspolitik 2, 383-405

Blanchard, O. (2006), European Unemployment: The Evolution of Facts and Ideas, in: Economic Policy 45, 5-59

Blundell, R. (2006), Earned Income Tax Credits: Impact and Optimality, in: Labour Economics 13, 423-443

Bosch, G./S. Lehndorff (2001), Working-Time Reduction and Employment: Experiences in Europe and Economic Policy Recommendations, in: Cambridge Journal of Economics 25, 209-243

Buslei, H./V. Steiner (1999), Beschäftigungseffekte von Lohnsubventionen im Niedriglohnbereich, Baden-Baden

Brennan, G./L. Lomasky (1984), Institutional Aspects of Merit Good Analysis, in: Finanzarchiv 41, 183-206

Calmfors, L./M. Hoel (1988), Worksharing and Overtime, in: Scandinavian Journal of Economics 90, 45-62

Carlberg, M. (1985), Makroökonomische Effekte einer Arbeitszeitverkürzung, in: Zeitschrift für Wirtschafts- und Sozialwissenschaften 105, 17-32 
Conrad, K./H. Koschel/A. Löschel (2005), Not Employed 37 Hours or Employed 41? A CGE Analysis for Germany, in: Centre for European Economic Research, Discussion Paper No. 05-42, Mannheim

Crépon, B./F. Kramaz (2002), Employed 40 Hours or Not Employed 39: Lessons from the 1982 Mandatory Reduction of the Workweek, in: Journal of Political Economy 110, $1355-1389$

Estevão, M./F. Sá (2008), The 35-Hour Workweek in France: Straightjacket or Welfare Improvement?, in: Economic Policy 55, 419-463

Dinlersoz, E. M./R. Hemández-Muurillo (2002), Did 'Right to Work' Work for Idaho?, in: Federal Reserve Bank of St. Louis Review 84(3), 29-41

Di Tella, R./R. J. MacCulloch/A. J. Oswald (2001), Preferences over Inflation and Unemployment: Evidence from Surveys of Happiness, in: American Economic Review 91, 335-341

Dolado, J. J./F. Felgueroso/J. F. Jimeno (2000), The Role of the Minimum Wage in the Welfare State, in: Swiss Journal of Economics and Statistics 136, 223-245

Elster, J. (1987) (ed.), The Multiple Self, Cambridge

- (1988), Is There (or Should There Be) a Right to Work?, in: A. Gutmann (ed.), Democracy and the Welfare State, Princeton

- (1989), Solomonic Judgments, Cambridge

Entorf, H. (1996), Strukturelle Arbeitslosigkeit in Deutschland: Mismatch, Mobilität und technischer Wandel, in: B. Gahlen/H. Hesse/H. J. Ramser (eds.), Arbeitslosigkeit und Möglichkeiten ihrer Überwindung, Tübingen, 139-170

Frank, R. H. (1985), Choosing the Right Pond: Human Behavior and the Quest for Status, New York

Frankfurt, H. G. (1971), Freedom of the Will and the Concept of a Person, in: Journal of Philosophy 68, 5-20

Frey, B. S./G. Kirchgässner (2002), Demokratische Wirtschaftspolitik: Theorie und Anwendung, 3. Auflage, München

Friedman, M. (1962), Capitalism and Freedom, Chicago

Furger, F. (1992), Moral oder Kapital? Grundlagen der Wirtschaftsethik, Zürich

Gäfgen, G. (1980), Ökonomische Implikationen ethischer Prinzipien, in: D. Duvendag/H. Siebert (eds.), Politik und Markt, Stuttgart-New York, 191-207

Gerlach, K./G. Stephan (1996), A Paper on Unhappiness and Unemployment in Germany, in: Economics Letters 52, 325-330

Gorz, A. (1989), Métamorphoses du travail, Quête du sens: Critique de la raison économique, Éditions Galilée, Paris; German translation: Kritik der ökonomischen Vernunft, Sinnfragen am Ende der Arbeitsgesellschaft, Berlin

Harvey, P. (2006), The Relative Cost of a Universal Basic Income and a Negative Income Tax, in: Basic Income Studies 1(2), Article 1

Harsanyi, J. C. (1975), Can the Maximin Principle Serve as a Basis of Morality? A Critique of John Rawls's Theory, in: American Political Science Review 69, 594-606

- (1977), Morality and the Theory of Rational Behaviour, in: Social Research 44, 623-656

Hayek, F. A. v. (1945), The Use of Knowledge in Society, in: American Economic Review $35,519-530$

Höffe, O. (1990), Gerechtigkeit als Tausch? Ein ökonomisches Prinzip für die Ethik, in: P. Ulrich (ed.), Auf der Suche nach einer modernen Wirtschafts ethik: Lernschritte zu einer reflexiven Ökonomie, Bern-Stuttgart, 91-102

- (1994), Tauschgerechtigkeit und korrektive Gerechtigkeit: Legitimationsmuster für Staatsaufgaben, in: D. Grimm (ed.), Staatsaufgaben, Baden-Baden, 713-737 
Howell, D. R./A. Glyn/D. Baker/J. Schmitt (2007), Are Protective Labor Market Institutions at the Root of Unemployment? A Critical Review of the Evidence, in: Capitalism and Society 2(1), Article 1

Huang, C./J. Chang/C. Lai/C. Lin (2002), Worker Productivity, Working Time Reduction, and the Short-Run and Long-Run Employment Effects, in: Scottish Journal of Political Economy 49, 357-368

Hunt, J. (1999), Has Work-Sharing Worked in Germany?, in: Quarterly Journal of Economics 114, 117-148

Kapteyn, A./A. Kalwij/A. Zaidi (2004), The Myth of Worksharing, in: Labour Economics 11, 293-313

Karanassou, M./H. Sala/D. J. Snower (2003), Unemployment in the European Union: A Dynamic Reappraisal, in: Economic Modelling 20, 237-273

Kirchgässner, G. (1995), Soziale Gerechtigkeit: Produktivkraft, Illusion oder regulative Idee: Einige Anmerkungen, in: A. Brandenberg (ed.), Zwischen Pragmatismus und Theorie: Auf der Suche nach neuen Wegen in der Wirtschaftspolitik, Bern, 173-192

- (1997), Auf der Suche nach dem Gespenst des Ökonomismus: Einige Bemerkungen über Tausch, Märkte und die Ökonomisierung der Lebensverhältnisse, in: Analyse \& Kritik 19, 127-152

- (1998), Ökologische Steuerreform: Utopie oder realistische Alternative, in: G. Krause-Junk (ed.), Die Zukunft des Steuersystems, Sonderheft der Zeitschrift für Wirtschafts- und Sozialwissenschaften, Berlin, 279-319

- (1998a), Globalisierung: Herausforderung für das 21. Jahrhundert, in: Aussenwirtschaft 53, 29-50

- (2008), Homo Oeconomicus: The Economic Model of Behaviour and Its Application in Economics and Other Social Sciences, New York

Knabe, A./R. Schöb (2008), Minimum Wage Incidence: The Case for Germany, CESifo Working Paper No. 2432, Munich

Koller, P. (2009), Work and Social Justice, in: Analyse $\& 3$ Kritik 31, 5-24

König, H./W. Pohlmeier (1987), Arbeitszeit und Beschäftigung: Eine ökonometrische Analyse, in: G. Bombach/B. Gahlen/A. E. Ott (eds.), Arbeitsmärkte und Beschäftigung: Fakten, Analysen, Perspektiven, Tübingen, 69-89

Kraft, K. (1988), Die Effekte einer Arbeitszeitverkürzung bei Berücksichtigung von Fixkosten und Überstunden, in: Jahrbücher für Nationalökonomie und Statistik 204, 316-326

- (1989), Arbeitszeitverkürzung, Beschäftigung und tatsächliche Arbeitszeit, in: Jahrbücher für Nationalökonomie und Statistik 206, 243-251

Kromphardt, J./B. Scheidt (1994), Chancen des 'zweiten Arbeitsmarktes', in: Wirtschaftsdienst 7/4, 615-622

Lange, O. (1936), On the Economic Theory of Socialism, in: Review of Economic Studies 4; reprinted in: B. E. Lippincott (1964) (ed.), On the Economic Theory of Socialism, New York, 57-142

Leu, R. E. et al. (2007), Erwerbsabhängige Steuergutschriften: Möglichkeiten und Auswirkungen einer Einführung in der Schweiz, Report on Behalf of the Federal Department of Finance, Berne

- /Ch. Eisenring (1998), Effizienz und Wirksamkeit von Sozialtransfers: Ein Beitrag zur aktuellen Diskussion, in: Aussenwirtschaft 53, 435-465

Maital, S. (1986), Prometheus Rebound: On Welfare-Improving Constraints, in: Eastern Economic Journal 12, 337-344 
Marimon, R./F. Zilibotti (2000), Employment and Distributional Effects of Restricting Working Time, in: European Economic Review 44, 1291-1326

Marx, K. (1844), Ökonomisch-philosophische Manuskripte, Leipzig

- /F. Engels (1848), Manifest der Kommunistischen Partei, Stuttgart

Mises, L. v. (1920), Die Wirtschaftsrechnung im sozialistischen Gemeinwesen, Archiv für Sozialwissenschaften 47; English translation in: I. M. Kirzner (ed.), Classics in Austrian Economics: A Sampling in the History of a Tradition, Band III, London, $22-30$

Moffitt, R. A. (2003), The Negative Income Tax and the Evolution of U.S. Welfare Policy, National Bureau of Economic Research, Working Paper Nr. 9751, Cambridge/MA

Moltmann, J. (ed.) (1979), Recht auf Arbeit-Sinn der Arbeit, München

Moore, W. J. (1998), The Determinants and Effects of Right-To-Work Laws: A Review of the Recent Literature, in: Journal of Labor Research 19, 445-469

Mundlak, G. (2007), The Right to Work: Linking Human Rights and Employment Policy, in: International Labour Review 146, 189-215

Nell-Breuning, O. v. (1985), Arbeitet der Mensch zuviel?, Freiburg-Basel-Wien

Nickel, S. (1997), Unemployment and Labor Market Rigidities: Europe versus North America, in: Journal of Economic Perspectives 11(3), 55-74

OECD (2008), Economic Outlook 84, Paris

Pfannkuche, W. (1996), Gibt es ein Recht auf Arbeit?, in: Rechtsphilosophische Hefte $5,97-113$

Rawls, J. (1971), A Theory of Justice, Cambridge/MA

Rippe, P. (1995), Gibt es ein Recht auf Arbeit?, in: Gesellschaft zur Förderung der ethischen Forschung, Arbeitsblätter 34, 55-72

Risse, M. (2007), A Right to Work? A Right to Holidays with Pay? Labor Rights as Human Rights, Harvard University, John F. Kennedy School of Government, Faculty Research Working Paper No. RWP07-058

Rhys-Williams, J. (1943), Something to Look Forward to, London

Sachverständigenrat z. Begutachtung der gesamtwirtschaftlichen Entwicklung (2007), Das Erreichte nicht verspielen: Jahres gutachten 2007/08, Statistisches Bundesamt, Wiesbaden

Sarfati, H./G. Bonoli (2002) (eds.), Labour Market and Social Protection Reforms in International Perspective: Parallel or Converging Tracks?, Aldershot

Schaber, P. (1996), Grundeinkommen ohne Leistungsbereitschaft?, in: Gesellschaft zur Förderung der ethischen Forschung, Arbeitsblätter 35, 63-70

Schelling, T. C. (1978), Egonomics, or the Art of Self-Management, in: American Economic Review, Papers and Proceedings 68(2), 290-294

- (1980), The Intimate Contest for Self-Command, in: Public Interest 60, 94-118

Schneider, B. (1995), Garantiertes Mindesteinkommen und gerechte Arbeitseinteilung, in: Gesellschaft zur Förderung der ethischen Forschung, Arbeitsblätter 34, 73-85

Schneider, F. (2007), Shadow Economies and Corruption all over the World: New Estimates for 145 Countries, in: Economics: The Open Access, Open Assessment EJournal No. 2007-9

- /D. H. Enste (2000), Shadow Economies: Size, Causes, and Consequences, in: Journal of Economic Literature 38, 77-114

Schöb, R./J. Weimann (2003), Kombilohn: Die Magdeburger Alternative, in: Perspektiven der Wirtschaftspolitik 4, 1-16

Sen, A. K. (1977), Rational Fools: A Critique of the Behavioral Foundations of Economic Theory, in: Philosophy and Public Affairs 6, 317-344 
Siebert, H. (1989), Kündigungsschutz und Sozialplanpflicht: Optimale Allokation von Risiken oder Ursache von Arbeitslosigkeit?, in: H. Scherf (ed.), Beschäftigungsprobleme hochentwickelter Volkswirtschaften, Berlin, 267-285

- (1997), Labor Market Rigidities: At the Root of Unemployment in Europe, in: Journal of Economic Perspectives 11(3), 37-54

Skans, O. N. (2004), The Impact of Working-Time Reductions on Actual Hours and Wages: Evidence from Swedish Register-Data, in: Labour Economics 11, 657-665

Sperling, I. (1994), Probleme des 'zweiten Arbeitsmarktes', in: Wirtschaftsdienst 74, $396-420$

Steinvorth, U. (1996), Das Recht auf Arbeit?, in: Rechtsphilosophische Hefte 5, 77-95

- (2009), The Right to Work and the Right to Develop One's Capabilities, in: Analyse und Kritik 31, 99-111

Stille, F./R. Zwiener (1983), Was bringt der Einstieg in die 35-Stunden-Woche?, in: DIW-Wochenbericht 50, 383-394

Stutzer, A./R. Lalive (2002), Soziale Arbeitsnorm und Arbeitslosigkeit in der Schweiz, in: Schweizerische Zeitschrift für Volkswirtschaft und Statistik 138, 293-316

Ulrich, P. (1995), Müssen wir die Arbeit neu verteilen?, in: Gesellschaft zur Förderung der ethischen Forschung, Arbeitsblätter 34, 41-53

- (1996), Arbeitswelt und Lebenswelt, in: Gesellschaft zur Förderung der ethischen Forschung, Arbeitsblätter 36, 17-28

- (1998), Arbeitspolitik in einer wohlgeordneten Gesellschaft: Eine wirtschaftsethische Perspektive, in: Th. Geiser/H. Schmid/E. Walter-Busch (eds.), Arbeit in der Schweiz des 20. Jahrhunderts: Wirtschaftliche, rechtliche und soziale Perspektiven, Bern, 359-381

- (2000), Arbeitspolitik für alle: Eine Einführung aus wirtschaftsethischer Sicht, in: P. Ulrich/Th. Maak/B. Dietschy (eds.), Arbeitspolitik für alle: Eine Debatte zur Zukunft der Arbeit, Bern et al., 9-25

Van Parijs, Ph. (1991), Why Surfers Should be Fed: The Liberal Case for an Unconditional Basic Income, in: Philosophy and Public Affairs 20, 101-131

- (1992), Basic Income Capitalism, in: Ethics 102, 465-484

- (1995), Real Freedom for All: What (If Anything) Can Justify Capitalism, Oxford

Weber, R. (1991), Existenzsicherung ohne Fürsorge? Die negative Einkommensteuer in Theorie und Praxis, Bern-Stuttgart

Weck, H. (1983), Schattenwirtschaft: Eine Möglichkeit zur Einschränkung der öffentlichen Verwaltung?, Frankfurt et al.

Widerquist, K. (2005), A Failure to Communicate: What (If Anything) Can We Learn from the Negative Income Tax Experiments?, in: Journal of Socio-Economics 34, 49-81 